\title{
PAANa-induced ductile SEI of bare micro-sized FeS enables high sodium-ion storage performance
}

\author{
Linjie Chen ${ }^{1}$, Keming Song ${ }^{2}$, Juan $\mathrm{Shi}^{2,3}$, Jiyu Zhang ${ }^{2}$, Liwei $\mathrm{Mi}^{3}$, Weihua Chen ${ }^{1,2^{*}}$, Chuntai Liu ${ }^{{ }^{*}}$ and \\ Changyu Shen ${ }^{1}$
}

\begin{abstract}
High-capacity metal chalcogenides often suffer from low initial coulombic efficiency (ICE) and serious capacity fading owing to the shuttle effect and volumetric expansion. Various carbon-coating and fixing methods were used to improve the above-mentioned performance. However, the synthesis processes of them are complex and time-consuming, limiting their engineering applications. Herein, polar polymer binder sodium polyacrylate (PAANa) is selected as an example to solve the problems of metal chalcogenides (bare micro-sized FeS) without any modification of the active materials. The special function of the polymer binder in the interface between the active material particles and the electrolytes demonstrates that a PAANa-induced network structure on the surface of ion sulfide microparticles not only buffers the mechanical stress of particles during discharging-charging, but also participates in forming a ductile solid electrolyte interphase (SEI) with high interfacial ion transportation and enhanced ICE. The cyclic stability and rate performance can be simultaneously improved. This work not only provides a new understanding of the binder on electrode, but also introduces a new way to improve the performance of batteries.
\end{abstract}

Keywords: sodium-ion batteries, solid electrolyte interphase, polymer binder, metal sulfides, initial coulombic efficiency

\section{INTRODUCTION}

The continuous growth of demand for energy greatly facilitates the development of clean and renewable energy, and efficient and environmentally friendly energy storage systems [1-4]. Sodium metal batteries [5,6], sodium-ion batteries (SIBs) [7-9], sodium-sulfur batteries [10-12] and high-temperature liquid sodium batteries [13] have widely attracted researchers' attention owing to their abundant natural resources and cost-effectiveness [14-16] in large-scale grid energy storage application for distributed energy sources. Recently, SIBs $[17,18]$ have been studied with other substances replacing the $\mathrm{Na}$ elemental anode, such as carbon and metal sulfides, to ensure the safety. Therefore, high-capacity, long-cycling-life anode is extensively expected for the application of SIBs.

Various types of materials [19-23], such as hard carbon [19], alloy-based materials [24,25], organic compounds [26,27], and metal sulfides [28], have been widely investigated as anodes for SIBs. Hard carbon is one of the promising anode materials for commercial production because of its cost effectiveness and simple processing technology. However, low initial coulombic efficiency (ICE) and reversible capacity hamper its practical application. Alloy-based materials with high special capacity (400-2600 $\mathrm{mA} \mathrm{h} \mathrm{g}^{-1}$ ) have received the attention of researchers. Nevertheless, serious volume changes (126\%$520 \%$ ) during charge/discharge lead to pulverization of the active materials and poor cycling performance. Organic compounds have the advantages of green chemistry controllable and designable chemical structure. However, these compounds dissolve in electrolytes and have poor electrical conductivity. Metal sulfides, especially iron sulfides, have several merits, namely, excellent economic benefits, environmental friendliness, high theoretical capacity, and good safety [29-32]. However, the pulverization of particles and volume expansion during cycling lead to a short lifespan [33-35]. Carbon-composite design [36], nanotechnology engineering [37], and other strategies $[38,39]$ have been developed to solve these problems. These architecture designs are time-consuming with complicated synthesis process and various expensive raw materials, thereby significantly hindering the large-scale engineering applications. Large micro-sized particles will

\footnotetext{
${ }^{1}$ National Engineering and Research Center for Advanced Polymer Processing Technology, Zhengzhou University, Zhengzhou 450001, China

${ }^{2}$ Green Catalysis Center, and College of Chemistry, Zhengzhou University, Zhengzhou 450001, China

${ }^{3}$ Center of Advanced Materials Research, Zhongyuan University of Technology, Zhengzhou 450007, China

* Corresponding authors (emails: chenweih@zzu.edu.cn (Chen W); ctliu@zzu.edu.cn (Liu C))
} 
enhance the volumetric energy density more than the nanotechnology, thereby implying great practical potential.

Polymer binder can fasten the active particles and conductive additives with current collector in the electrodes; these materials are often used in batteries industry to improve batteries' performance, especially the cycling stability [40]. Poly(vinylidene fluoride) (PVDF) is the most widely used in lithium-ion batteries (LIBs) and SIBs among various binders for many years [41]. However, PVDF needs to be dissolved in $N$-methyl pyrrolidone, which is a toxic and environmentally polluting reagent, for preparing the electrode. Water-based binders, such as polyacrylic acid [42], carboxymethyl cellulose (CMC) [43], and gum arabic [44], are environmentally friendly and inexpensive. Those binders with carboxyl groups on the polymer chains can form chemical or hydrogen bond with hydroxyl on the surface of silicon particles in LIBs. Conductive [45,46] and self-healing polymer binders [47] have also been applied for specific functions, such as enhancing the conductivity, repairing electrodes' crack [48] and extending the voltage window [49]. However, the understanding of the function of polymer binder in the construction of solid electrolyte interphase (SEI) and coulombic efficiency is constrained even though they are important in keeping the cycling stability of anodes [50].

Herein, an environmentally friendly water-based sodium polyacrylate (PAANa) is selected as an example to investigate its function on the micro-sized FeS anode without any modification for SIBs. This PAANa is also used in the construction of SEI, apart from its good binding ability to prevent the loss of active materials. PAANa can improve the ICE, cycling stability, and rate performance. This work provides not only a new understanding of binders on electrode but also insights into the new way to improve the performance of batteries.

\section{EXPERIMENTAL SECTION}

\section{Materials preparation}

FeS was prepared by simple thermal treatment of $\mathrm{FeS}_{2}$ precursor which was synthesized through a solvent thermal method [51]. Firstly, $2 \mathrm{mmol} \mathrm{FeSO}_{4} \cdot 7 \mathrm{H}_{2} \mathrm{O}, 10$ mmol urea and $12.5 \mathrm{mmol}$ sublimed sulfur were added into a mixed solvent $(30 \mathrm{~mL} \mathrm{~N}, \mathrm{~N}$-dimethylformamide (DMF) and $40 \mathrm{~mL}$ ethylene glycol (EG)). Then the mixture was poured into a $100-\mathrm{mL}$ Tefon-lined sealed autoclave and kept at $180^{\circ} \mathrm{C}$ for $12 \mathrm{~h}$. The product was washed with deionized water and alcohol. After drying in vacuum at $80^{\circ} \mathrm{C}$ for $12 \mathrm{~h}$, the precursor $\mathrm{FeS}_{2}$ was annealed at $800^{\circ} \mathrm{C}$ in argon for $2 \mathrm{~h}$ to obtain FeS.

\section{Electrochemical measurement}

To prepare the electrode, FeS, acetylene black $(\mathrm{AB})$, and the binder (PAANa or CMC, the binders PAANa and CMC were used without any treatment.) were mixed in a 70:15:15 wt.\% ratio with deionized water as the solvent. Gels could be formed by stiring the mixed slurry, and then the uniform slurry was coated on the copper foil and cut into $13 \mathrm{~mm}$ round pieces after being dried at $60^{\circ} \mathrm{C}$ for $24 \mathrm{~h}$. The loading of electrode materials was $0.8-$ $1.06 \mathrm{mg} \mathrm{cm}^{-2}$. The half cells (CR2025) were assembled in argon-filled glove box with metal sodium as the counter electrode and reference electrode, and glass fiber as the separator. $\mathrm{NaCF}_{3} \mathrm{SO}_{3}\left(1 \mathrm{~mol} \mathrm{~L}^{-1}\right)$ dissolved in diethylene glycol dimethyl ether (DGM) was selected as the electrolyte. The galvanostatic charge-discharge measurements were performed with a NEWARE battery test system at a voltage range of $0.1-3.0 \mathrm{~V}$. Before the cycling process at 1 , 3 and $5 \mathrm{C}\left(1 \mathrm{C}=609 \mathrm{~mA} \mathrm{~h} \mathrm{~g}^{-1}\right)$, the cell was activated for three cycles at $0.1 \mathrm{C}$. The cyclic voltammetry $(\mathrm{CV})$ experiments were conducted with a CHI600e electrochemical workstation. CV curves were recorded at a constant scan rate of $0.1 \mathrm{mV} \mathrm{S}^{-1}$ between 0.1 and $3.0 \mathrm{~V} v s$. $\mathrm{Na} / \mathrm{Na}^{+}$. Electrochemical impedance spectroscopy (EIS) was recorded on the CHI604e electrochemical workstation by using $5 \mathrm{mV}$ of alternating voltage and frequency ranging from $10 \mathrm{mHz}$ to $100 \mathrm{KHz}$. Galvanostatic intermittent titration (GITT) measurement was performed by discharging and charging the cells for $10 \mathrm{~min}$ at $0.2 \mathrm{C}$ followed by a 1-h relaxation [52] and the GITT curves were tested in the $3^{\text {rd }}$ cycle.

\section{Materials characterization}

Scanning electron microscope (SEM, ZEISS Merlin Compact) with energy dispersive X-ray spectroscopy (EDX, Oxford X-Max), and X-ray photoelectron spectroscopy (XPS, Thermo Escalab 250Xi) were used to characterize the morphology and surface chemical composition of the active materials and electrodes. In-depth analysis of SEI component of the electrode characterized by XPS using Ar ion sputtering and the etching rate was about $0.26 \mathrm{~nm} \mathrm{~s}^{-1}$ based on the measurement of the standard substance $\mathrm{TaS}_{2}$ by the instrument. The Fourier transform infrared (FT-IR) spectra were used to characterize the structure of polymer binders and electrodes. The crystal information of FeS was characterized by X-ray diffraction (XRD, X' Pert PRO) with a scaning rate of $8^{\circ} \mathrm{min}^{-1}$.

\section{RESULTS AND DISCUSSION}

The micro-sized FeS was synthesized via a solvothermal method [53] (Fig. S1). The XRD pattern of the as- 
synthesized FeS is shown in Fig. 1a and the diffraction peaks are assigned to FeS (JCPDF No. 89-6926). The slurry of the electrode components can form stable gels according to the favorable gelatinization feature of the PAANa binder in water (Fig. 1b). However, slurry with CMC binder is sticky liquid with mobility. The gel-like electrode slurry has a stable structure, and the components of electrode are uniformly distributed (Fig. 1f, g). Fig. $1 \mathrm{~d}$ demonstrates that the PAANa binder has a flexible chain structure. The CMC molecule has a complex sixelement ring structure and poor molecular flexibility (Fig. S2). At the same mass, PAANa binder could provide more polar groups $\left(-\mathrm{COO}^{-}\right)$than those of the $\mathrm{CMC}$ binder; thus, it can form chelation with $\mathrm{FeS}$ and improve the adhesion stress. The prepared electrode slice with PAANa binder, denoted as the FeS-PAANa electrode, shows a flat surface after drying (Fig. 1c and Fig. S3a). The obtained composite electrode displays a network structure with coating of PAANa binder on the surface of the FeS particles and uniform embedding of the con- ductive agent (Fig. 1f). By contrast, the FeS-CMC electrode (the electrode with CMC binder) has a mass of bare FeS particles exposed, and the CMC binder is fibrous in the electrode (Fig. S3b, c). This network structure is derived from chelation between the FeS and polar sodium carboxylate group (-COONa) in PAANa's soft chains (Fig. 1d); the structure can also buffer the mechanical stress of particles during discharging-charging [54]. The uniform adherence of PAANa on the surface of the FeS particles is shown in Fig. 1f, g. In the FT-IR spectroscopy (Fig. 1e), the main absorption peaks of PAANa binder at 1573.89 and $1404.01 \mathrm{~cm}^{-1}$ are related to $-\mathrm{COO}^{-}$. The absorption peaks of $-\mathrm{COO}^{-}$shift to low wavenumbers at 1532.14 and $1386.14 \mathrm{~cm}^{-1}$ [55]. This finding indicates that the chemical interaction might be from two aspects. Firstly, carboxylic groups in PAANa can bond with the unsaturated orbitals of Fe in the FeS interface. Secondly, FeS in the dispersant of water can ionize a small amount of Fe ions, which, as ionic cross-linker, provides metal coordination interactions with carboxylic groups; thus, a
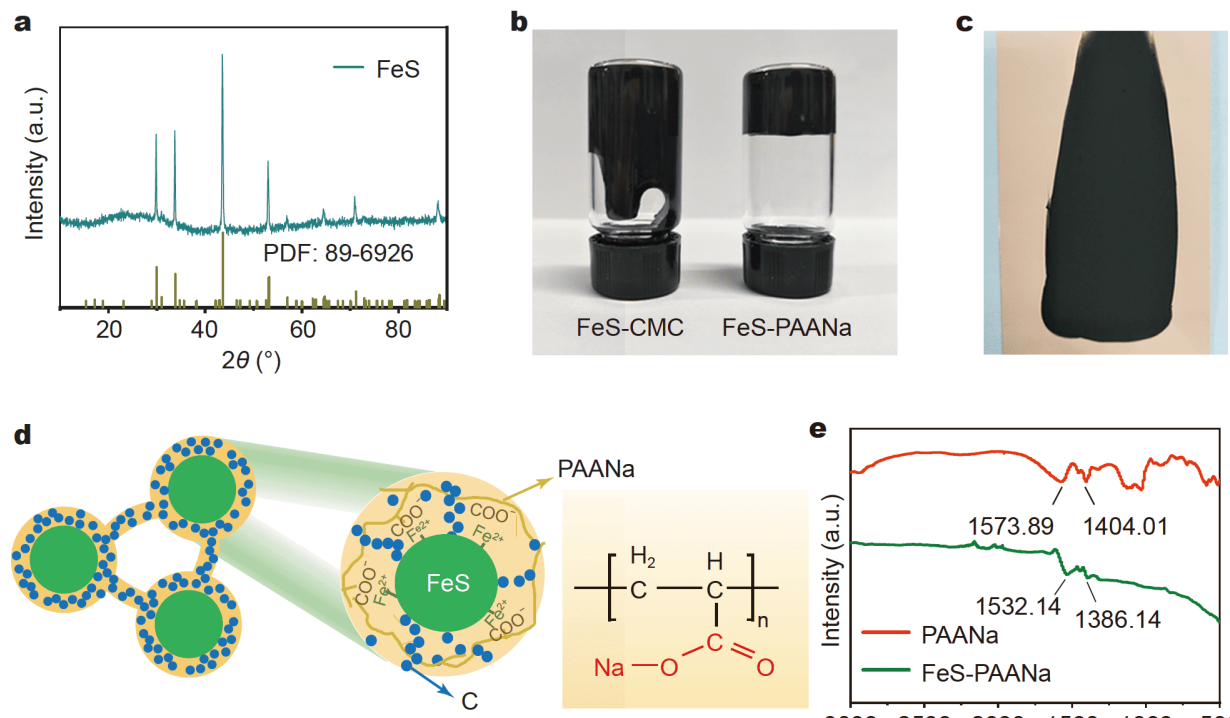

PAANa

FeS-PAANa
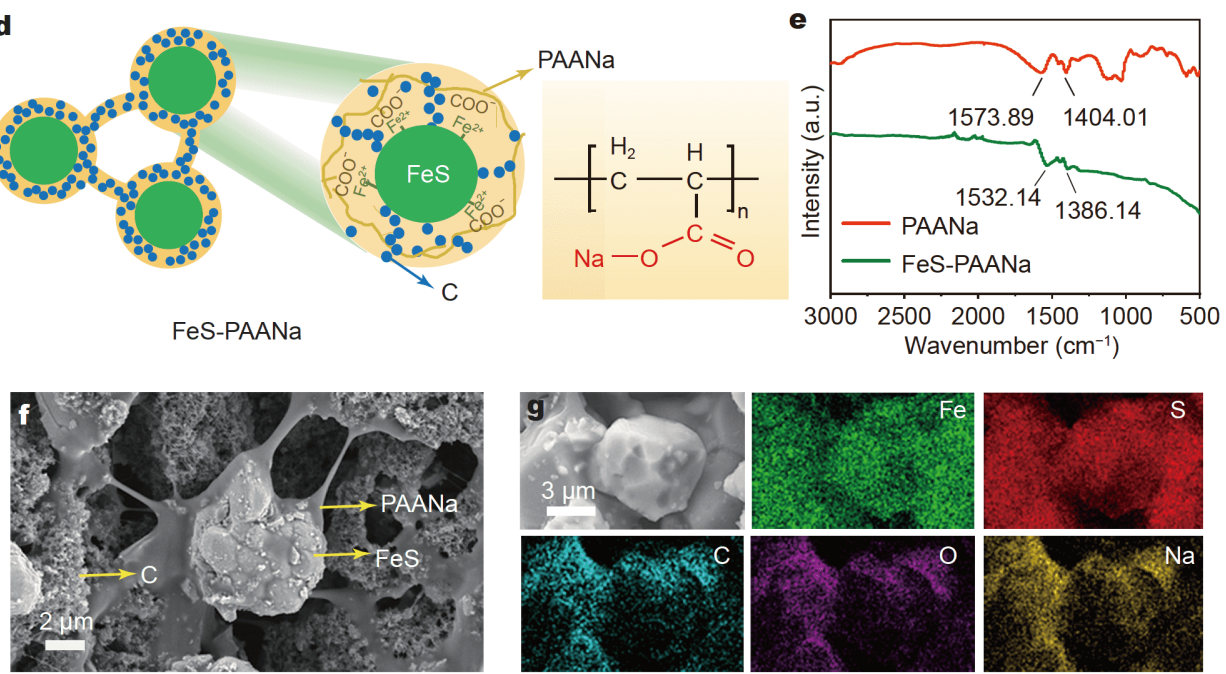

Figure 1 The morphology and component characterization. (a) XRD pattern of FeS, (b) digital images of the slurries for FeS-PAANa and FeS-CMC electrodes, respectively, and (c) FeS-PAANa electrode with the slurry coated on a copper foil after drying. (d) Scheme of the network structure of FeSPAANa electrode and the molecular structure formula of PAANa. (e) FT-IR spectra of PAANa and FeS-PAANa electrodes. (f) SEM image of the FeSPAANa electrode after freeze-drying. (g) SEM image of the FeS-PAANa electrode and the corresponding EDS mapping of elements Fe, S, C, O and Na. 
loose network to fix iron sulfide particles is maintained [56]. The network structure of the FeS-PAANa electrode helps in buffering the stress caused by the volume changes and keeping the composites of electrode closely in contact.

The electrochemical performance of the FeS-PAANa electrodes was tested and shown in Fig. 2 and Fig. S4a. In Fig. $2 \mathrm{a}$, the irreversible sharp peak at $0.81 \mathrm{~V}$ in the first cathodic scan of the FeS-PAANa electrode is attributed to the formation of SEI film [57]. In the subsequent two scans, the peaks at $0.34,0.75,0.921 .02 \mathrm{~V}$, and at 0.21 , $0.34 \mathrm{~V}$ are related to the reduction and conversion reactions, respectively $[58,59]$. In contrast with those of FeSCMC electrode in Fig. 2d, the FeS-PAANa electrode presents better reversibility. Fig. $2 \mathrm{~b}$ shows that the discharge curves present a long plateau at $0.81 \mathrm{~V}$ in initial discharge owing to the formation of SEI film. In contrast with the first cycle, the bulge at $0.75 \mathrm{~V}$ in the second cycle is due to the transformation reaction of FeS [60]. The charge/discharge profiles of the FeS-PAANa electrode are overlapped, thereby illustrating excellent reversibility of FeS-PAANa electrode. Meanwhile, the charge/discharge curves of the FeS-CMC electrode are fluctuating in the following cycles, thereby indicating poor cycling performance. The FeS-PAANa electrode demonstrates high reversible capacity of $577.84 \mathrm{~mA} \mathrm{~h} \mathrm{~g}^{-1}$ at the first cycle and $511.52 \mathrm{~mA} \mathrm{~h} \mathrm{~g}^{-1}$ after 100 cycles, repectively (Fig. 2c). However, the FeS-CMC electrode displays a low reversible capacity of $491.30 \mathrm{~mA} \mathrm{~h} \mathrm{~g}^{-1}$ at the first cycle and decreases to $169.75 \mathrm{~mA} \mathrm{~h} \mathrm{~g}^{-1}$ after 100 cycles. The excellent cycle performance of the FeS-PAANa electrode is attributed to the obtained network structure of the electrode that can buffer the mechanical stress of particles during discharging-charging and maintain the electrode
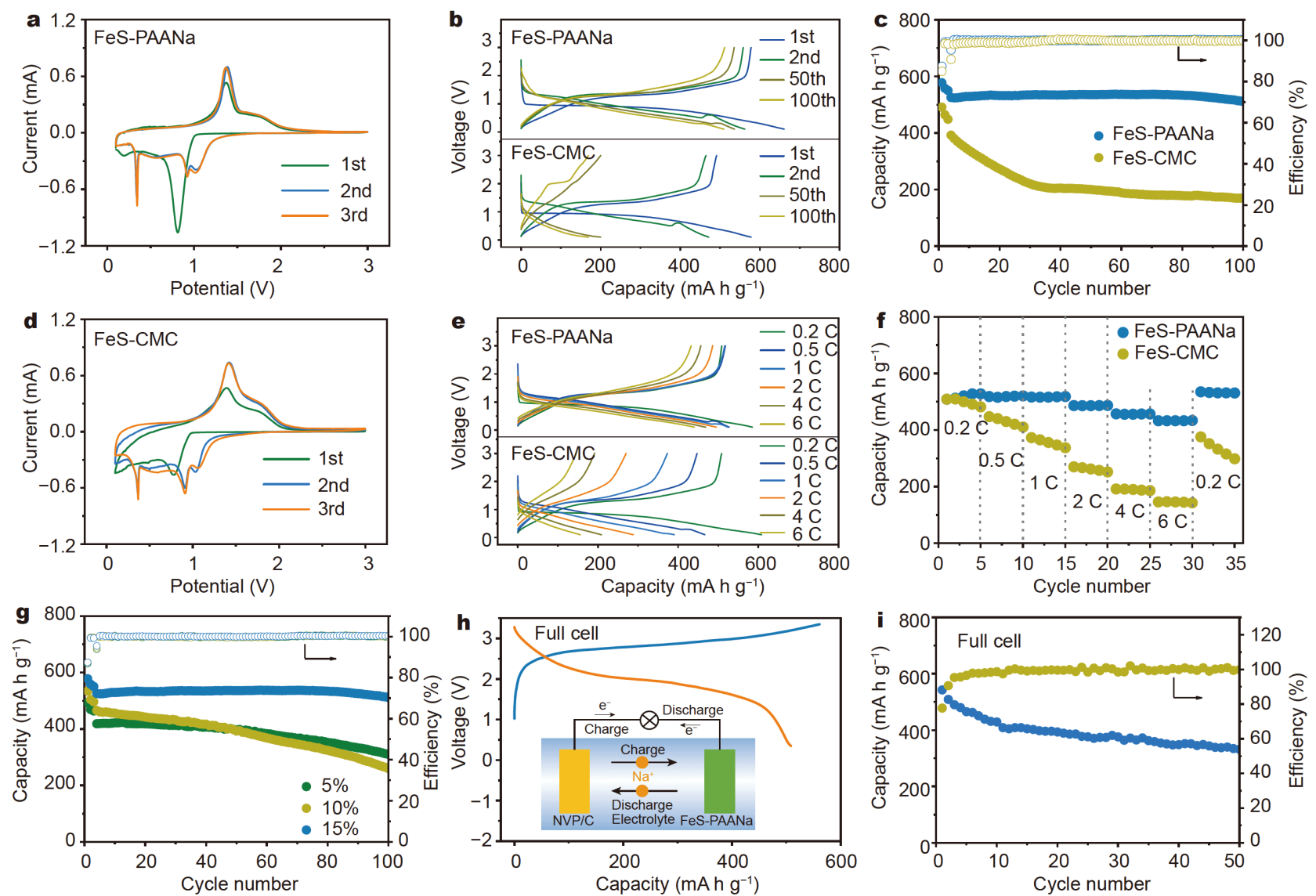

Figure 2 Sodium storage performance: CV curves of (a) FeS-PAANa and (d) FeS-CMC electrodes, respectively, at a scan rate of $0.10 \mathrm{mV} \mathrm{s}{ }^{-1}$ between 0.1 and $3.0 \mathrm{~V}\left(v s . \mathrm{Na} / \mathrm{Na}^{+}\right)$. Charge-discharge curves of FeS-PAANa and FeS-CMC electrodes, respectively, (b) in different cycles and (e) at different current densities. (c) Cycling performance of FeS-PAANa and FeS-CMC electrodes in voltage range of 0.1-3 V for 100 cycles at a current density of 1 C. (f) Rate performance of FeS-PAANa and FeS-CMC electrodes. (g) Cycling performance of FeS-PAANa electrodes with different contents of PAANa binder. (h) Charge-discharge curves of a full cell in the second cycle and its schematic image. (i) Cycle performance of the full cell at a current density of $0.5 \mathrm{C}$. 
contact, thereby prolonging the cycle life. The ICE of the FeS-PAANa electrode is $87.40 \%$, which is higher than that of the FeS-CMC electrode (84.90\%). The FeS with PAANa binder displays higher ICE (87.40\%) and excellent cyclic stability with a capacity retention of $88.5 \%$ after 100 cycles at $1.64 \mathrm{~A} \mathrm{~g}^{-1}$ than the other reported electrode materials that used the CMC and PVDF binders (Table S1). The high ICE illustrates less decomposition of electrolyte in the FeS-PAANa electrode with good electrochemical reversibility of FeS. The reduced exposed surface decreases the decomposition of electrolyte due to the covering of the PAANa binder on the surface of the electrode, thereby leading to high ICE in FeS-PAANa electrode. During the following cycles, the coulombic efficiency of the FeS-PAANa electrode is stable.

The specific capacities of the FeS-PAANa electrode are 508.76, 517.85, 516.18, 486.15, 456.91, and $432.43 \mathrm{~mA} \mathrm{~h} \mathrm{~g}^{-1}$ at current densities of $0.2,0.5,1,2,4$, and $6 \mathrm{C}$, respectively (Fig. 2f). By contrast, the FeS-CMC electrode shows a high specific capacity of $508.43 \mathrm{~mA} \mathrm{~h} \mathrm{~g}^{-1}$ at $0.2 \mathrm{C}$, but only $145.21 \mathrm{~mA} \mathrm{~h} \mathrm{~g}^{-1}$ at $6 \mathrm{C}$. As shown in Fig. 2e, the FeS-PAANa electrode exhibits outstanding rate performance, while the reversible capacity of the FeS-CMC electrode rapidly declines with the increase in the current densities. The excellent kinetic performance of the FeS-PAANa electrode is attributed to the porous network structure, which facilitates the infiltration of electrolyte, improves the interfacial contact, and shortens the diffusion distance of $\mathrm{Na}^{+}$. The conductive agent carbon uniformly distributes in the network structure and efficiently contacts with FeS particles, thereby highly improving the electronic conductivity. The above-mentioned reasons indicate that the FeS-PAANa electrode has excellent reaction kinetics. The cycle performance of the FeS-PAANa electrode improves with the increase in the content of the PAANa binder in electrode (Fig. $2 \mathrm{~g}$ and Fig. S4b). Such performance achieves an optimal effect when the binder content is $15 \mathrm{wt} \%$. The assembled full cell (Fig. 2h) with $\mathrm{Na}_{3} \mathrm{~V}_{2}\left(\mathrm{PO}_{4}\right)_{3} / \mathrm{C}(\mathrm{NVP} / \mathrm{C})$ as cathode (Fig. S4c) shows favorable cycle performance. This cell demonstrates a discharge capacity of $542.37 \mathrm{~mA} \mathrm{~h} \mathrm{~g}^{-1}$ (calculated on the basis of the FeS mass) at the current density of $0.5 \mathrm{C}$ with an ICE of $77.71 \%$ (Fig. 2i), thereby showing promising application prospect.

The surface chemistry of the FeS-PAANa electrode was investigated via XPS technique. In bare FeS material, the strong peaks of $\mathrm{C}-\mathrm{C}$ and $\mathrm{C}=\mathrm{O} / \mathrm{CO}_{3}{ }^{2-}$ mainly result from the pollutants (Fig. 3a). The peaks at 161.27, 163.40, and $166.67 \mathrm{eV}$ correspond to $\mathrm{S}^{2-}$ in FeS, polysulfide $\mathrm{S}-\mathrm{S}$, and oxidized group $\mathrm{SO}_{x}$, respectively [61]. The peak at
$529.91 \mathrm{eV}$ relates to $\mathrm{O}-\mathrm{Fe}$, which originates in the oxidation of FeS in the air. After PAANa is introduced, the FeS-PAANa electrode shows an obvious increase of the $\mathrm{CH}_{2}-$ and $\mathrm{O}=\mathrm{C}-\mathrm{O}$ peak areas, and $\mathrm{Na}$ auger also appears in the $\mathrm{O}$ spectrum, which are characteristics of the PAANa binder. The incomplete coating of PAANa on the surface of FeS particles decreases the contents of the Fe and S peaks (Fe: 0.4 at.\% and S: 0.6 at.\% of all element peak areas in survey spectrum). This finding is inconsistent with the SEM result. After cycling, the atomic fractions of $\mathrm{Na}, \mathrm{F}$, and $\mathrm{O}$ from the FeS-PAANa electrode increase $(\sim 5.6,0$, and 18.89 at.\% at pristine and $\sim 6.1,0.4$, and 20.4 at. $\%$ at discharge state, respectively). Meanwhile, the atomic fraction of Fe shows a completely opposite trend changing from $\sim 0.4$ to $\sim 0.2$ at. $\%$, thereby indicating the formation of the SEI layer [62]. The appearance of C$\mathrm{F}$ and $\mathrm{NaF}$ in the $\mathrm{F}$ spectrum is also observed (Fig. S5). The $\mathrm{C}=\mathrm{O} / \mathrm{CO}_{3}{ }^{2-}$ peak content of the FeS-PAANa electrode increases from 11.9 at.\% at pristine to 14.4 at.\% at discharge state, suggesting the formation of $\mathrm{Na}_{2} \mathrm{CO}_{3} /$ $\mathrm{Na}_{2} \mathrm{CO}_{2} \mathrm{R}$ in SEI. The increase of the $\mathrm{C}-\mathrm{C}$ content might be due to the polyether materials produced in SEI. In the $\mathrm{S}$ spectrum of Fig. 3a, the relative amount of S-S/C-S located at $163.6 \mathrm{eV}$ distinctively increases from 17.8 at.\% of FeS-PAANa to 37 at.\% at discharge state, thereby indicating the existence of organic materials $\mathrm{RSO}_{3} \mathrm{Na}$ that originate from the decomposition of electrolyte salts. The common organic components of SEI layer (C-O related, e.g., sodium alkoxides $\left[\mathrm{RCH}_{2} \mathrm{ONa}\right]$ ) are not observed in the $\mathrm{C}$ and $\mathrm{O}$ spectra [63]. The PAANa layer on the FeS particles efficiently plays the role of organic layer of SEI because of the similar chemical property of the organic component with PAANa with the similar group, thereby preventing the further intrusion of electrons and the excessive decomposition of the electrolyte (Fig. 3b). Therefore, PAANa binder can reduce the decomposition of the electrolyte during the formation of SEI and finally enhance the ICE of the FeS-PAANa electrode.

The SEI composition distribution was further investigated by XPS using Ar ion sputtering (Fig. 3c). After etching, the peaks of $\mathrm{NaF}$ and $\mathrm{O}=\mathrm{C}-\mathrm{O}$ strongly increase, and those of $\mathrm{C}=\mathrm{O} / \mathrm{CO}_{3}{ }^{2-}$ slightly increase; the peaks related to $\mathrm{C}-\mathrm{F}$ are weakened. This finding indicates that the organic components are mainly distributed near the out layer, and the interior of the SEI is mainly composed of inorganic species [62]. The $\mathrm{Na}$ and $\mathrm{O}$ contents show a completely increasing trend with etching depth, thereby further confirming that inorganics mainly exist in the interior layer, which is consistent with previous discussion. The S-S/C-S peak related to $\mathrm{RSO}_{3} \mathrm{Na}$ (Fig. S6) 


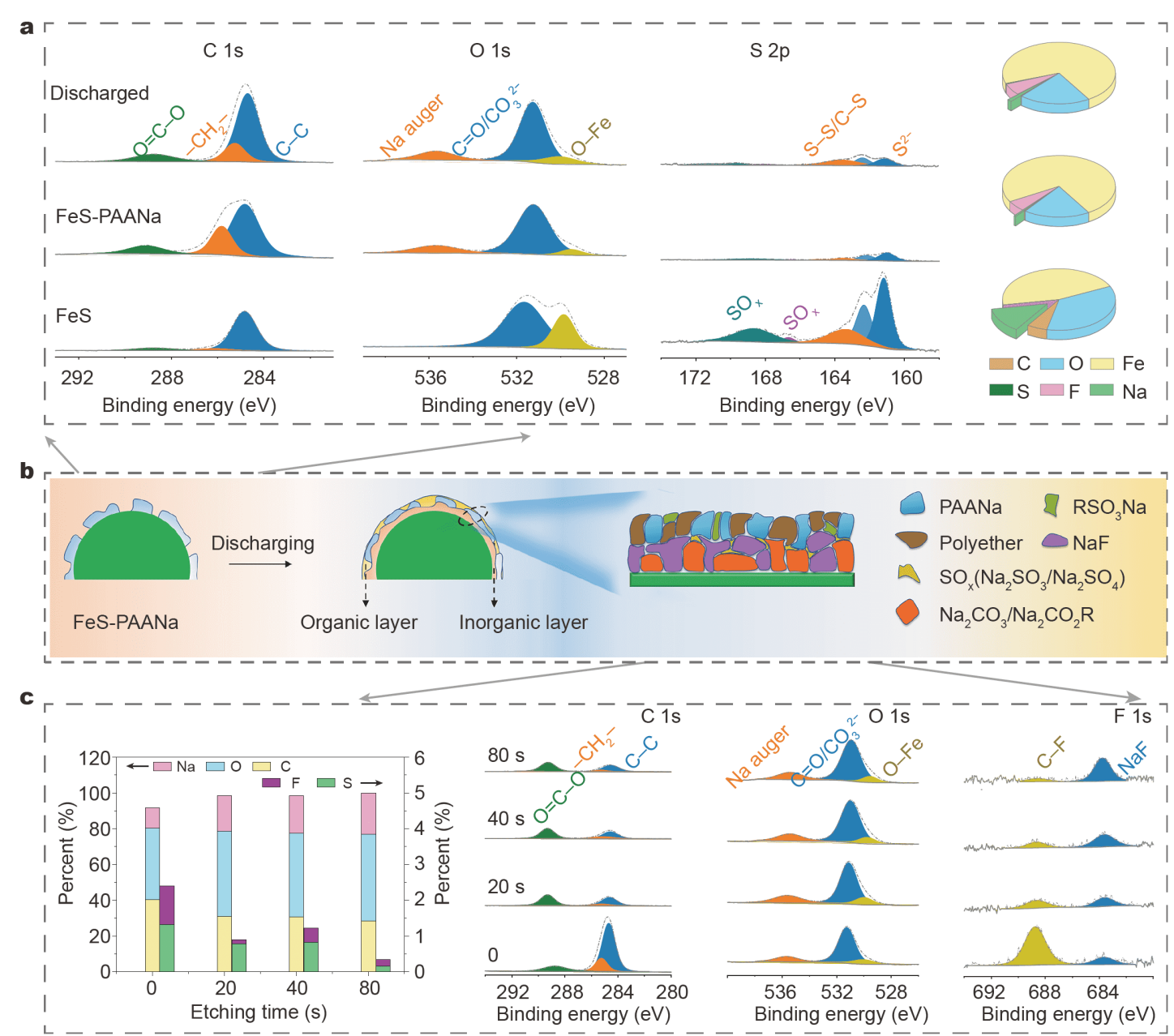

Figure 3 (a) High-resolution XPS patterns and surface composition (pie graph) of the FeS material, FeS-PAANa electrode at pristine and discharge state, respectively. (b) Scheme of interface evolution, SEI composition and structure. (c) Elemental percentage variation with increasing etching time (left); in-depth analysis of SEI component of FeS-PAANa electrode at discharge state (right).

sharply decreases after an etching time of $20 \mathrm{~s}$. The $\mathrm{SO}_{x}$ peak increases when the etching time is $40 \mathrm{~s}$. However, the $\mathrm{SO}_{x}$ content decreases at an etching time of $80 \mathrm{~s}$. These changes imply that the S-based substances mainly distribute at the out layer of organic and inorganic layer of SEI. The C content dramatically decreases from $\sim 46$ at.\% at the surface to 30.9 at.\% at 20 s etching with the increase in etching depth and remains stable at approximately 30 at.\% till $40 \mathrm{~s}$ etching. Then it slightly declines at $80 \mathrm{~s}$ etching ( 28 at.\%). These changes suggest that the thickness of organic layer of SEI is thinner compared with that of the reported studies [14,64], owing to PAANa involved in the construction of the out layer of SEI. The formed SEI consists of an organic layer with high molecular weight and mechanical strength at the exterior, which could improve the mechanical property of
SEI layer and the stability of the interface.

The reaction kinetics of electrodes were studied via EIS [65] and galvanostatic intermittent titration (GITT) measurements [66]. The Nyquist plots of the FeS-PAANa and FeS-CMC electrodes after discharging in the first cycle in Fig. $4 \mathrm{a}$ and the simulation results in Fig. $4 \mathrm{~b}$ show that the SEI resistance $\left(R_{\mathrm{SEI}}\right)$ and charge transfer resistance $\left(R_{\mathrm{ct}}\right)$ of the FeS-PAANa electrode are 1.69 and $3.48 \Omega$, which are smaller than those of the FeS-CMC electrode (3.59 and $7.22 \Omega$ ), respectively. The result is consistent with the formed thin SEI film of the FeSPAANa electrode. Fig. $4 \mathrm{c}$ and Fig. S7 show that the activation energy $\left(E_{\mathrm{a}}\right)$ values of the FeS-PAANa and FeS$\mathrm{CMC}$ electrodes are 12.93 and $17.32 \mathrm{~kJ} \mathrm{~mol}^{-1}$, respectively. This result is due to the fast transport of $\mathrm{Na}^{+}$in the SEI film of the FeS-PAANa electrode, thereby resulting in 

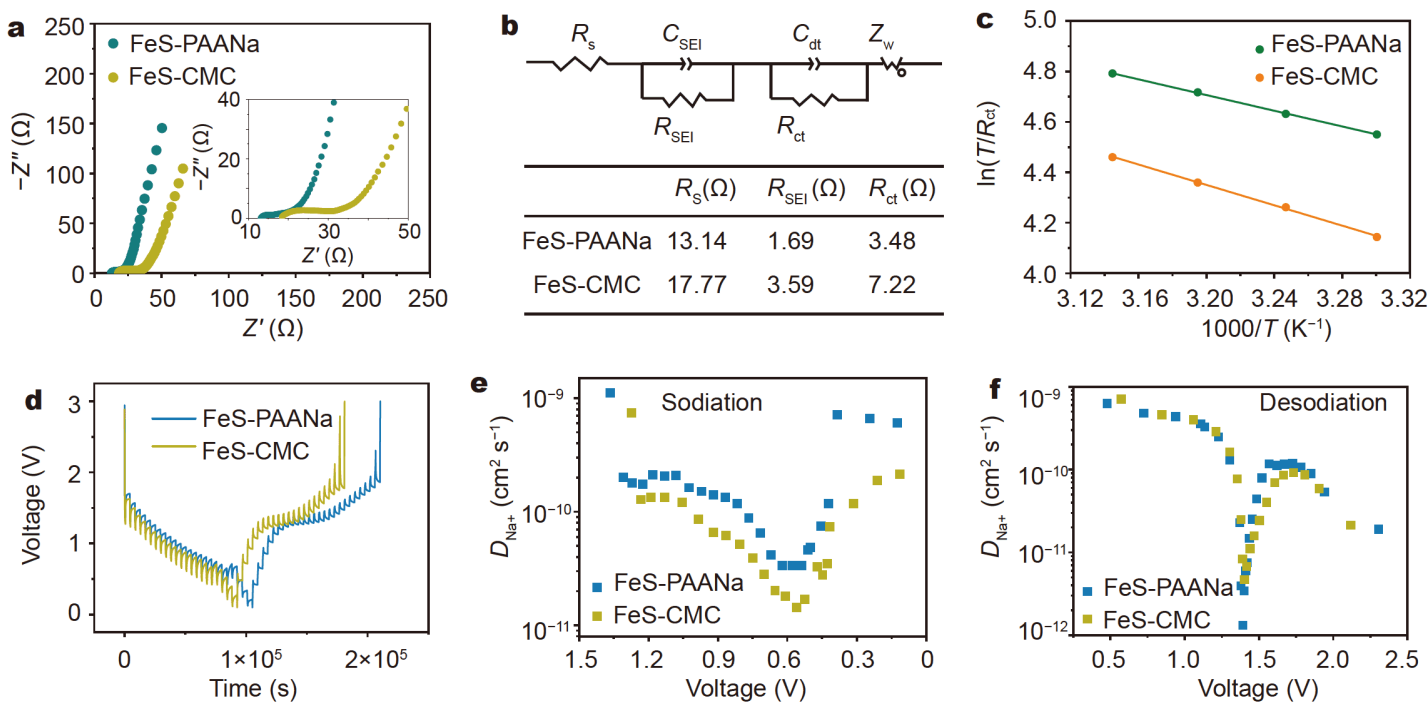

Figure 4 The reaction kinetics of the FeS-PAANa and FeS-CMC electrodes. (a) Nyquist plot after discharging in the first cycle. (b) Equivalent circuit used to fit the experimental data and the values of $R_{\mathrm{s}}, R_{\mathrm{SEI}}$ and $R_{\mathrm{ct}}$ after discharging in the first cycle. (c) Activation energy calculation: the relationship between $\ln \left(T / R_{\mathrm{ct}}\right)$ and $1000 / T$. (d) GITT profiles, $\mathrm{Na}^{+}$diffusion coefficients of (e) sodiation and (f) desodiation in the third cycle.

excellent reaction kinetics. The diffusion coefficient of sodium ion $\left(D_{\mathrm{Na}}\right)$ in FeS-PAANa was calculated from GITT in Fig. 4d and Fig. S8 by using Fick's second law and Equation (S1) [67]. Fig. 4e, $\mathrm{f}$ demonstrate that the $D_{\mathrm{Na}+}$ of the FeS-PAANa electrode is higher than that of the FeS-CMC electrode, thereby showing the fast ion diffusion property. $E_{\mathrm{a}}$ is also used to understand the kinetic characteristics of the transportation of $\mathrm{Na}^{+}$in the SEI film. Therefore, the desirable surface chemistry and network structure of the FeS-PAANa electrode greatly contribute to the low impedance, higher ion transport property, and enhanced rate performance.

After 50 cycles, the co-constructed SEI and morphology of the FeS-PAANa electrode were investigated. Fig. 5a demonstrates that the peaks at 288.86, 285.54, and $284.78 \mathrm{eV}$ belong to $\mathrm{O}=\mathrm{C}-\mathrm{O},-\mathrm{CH}_{2^{-}}$, and $\mathrm{C}-\mathrm{C}$, and those at 535.67 and $531.36 \mathrm{eV}$ are related to $\mathrm{Na}$ auger and $\mathrm{C}=\mathrm{O} /$ $\mathrm{CO}_{3}{ }^{2-}$ [59], respectively, which come from the components of SEI. The peaks at 166.51, 168.97, 170.21, 688.85, and $684.25 \mathrm{eV}$ corresponding to $\mathrm{SO}_{x}, \mathrm{C}-\mathrm{F}$, and $\mathrm{NaF}$ [61] are stronger than those in the discharge state of the first cycle (Fig. 3a). This finding indicates that the co-constructed SEI film remains stable after 50 cycles, but a small amount of electrolyte decomposition is present. The surface of the FeS-PAANa electrode remains intact, and the FeS particles keep integrated after 100 cycles (Fig. 5b, c and Fig. S9a). By contrast, the FeS-CMC, electrode materials fall off from copper foil, and the particles are broken (Fig. 5b, d and Fig. S9b). Therefore, the network structure and co-constructed SEI film in the FeS-PAANa electrode can protect the FeS particles from crushing and losing due to the volume changes during cycling and enhance the cycle stability.

\section{CONCLUSIONS}

In this work, water-based PAANa was selected as binder to improve the electrochemical performance of microsized FeS in SIBs. The PAANa binder could help FeS to construct a network structure, including conductive carbon, via chelation between the polar sodium carboxylate group (-COONa) in PAANa's soft chains and the Fe ions of FeS. The obtained network structure electrode of FeSPAANa could buffer the pressure caused by volume change and keep the electrode intact. On the one hand, the PAANa binder on the electrode surface could reduce the exposed surface and decrease the decomposition of electrolyte, thereby enhancing the ICE of the FeS-PAANa electrode. On the other hand, PAANa binder could also participate in forming a co-constructed SEI film with it involved in the organic layer. The co-constructed SEI film with preferable mechanical property and stability, improved the cycle stability of SIBs owing to the higher molecular weight and mechanical strength of the PAANa polymer compared with those of small molecules. The obtained FeS-PAANa electrode showed high reversible capacity of $577.84 \mathrm{~mA} \mathrm{~h} \mathrm{~g}^{-1}$ in the first cycle, ICE as high as $87.40 \%$, and capacity retention of $88.52 \%$ after 100 cycles. Given the desirable surface chemistry, the FeS- 

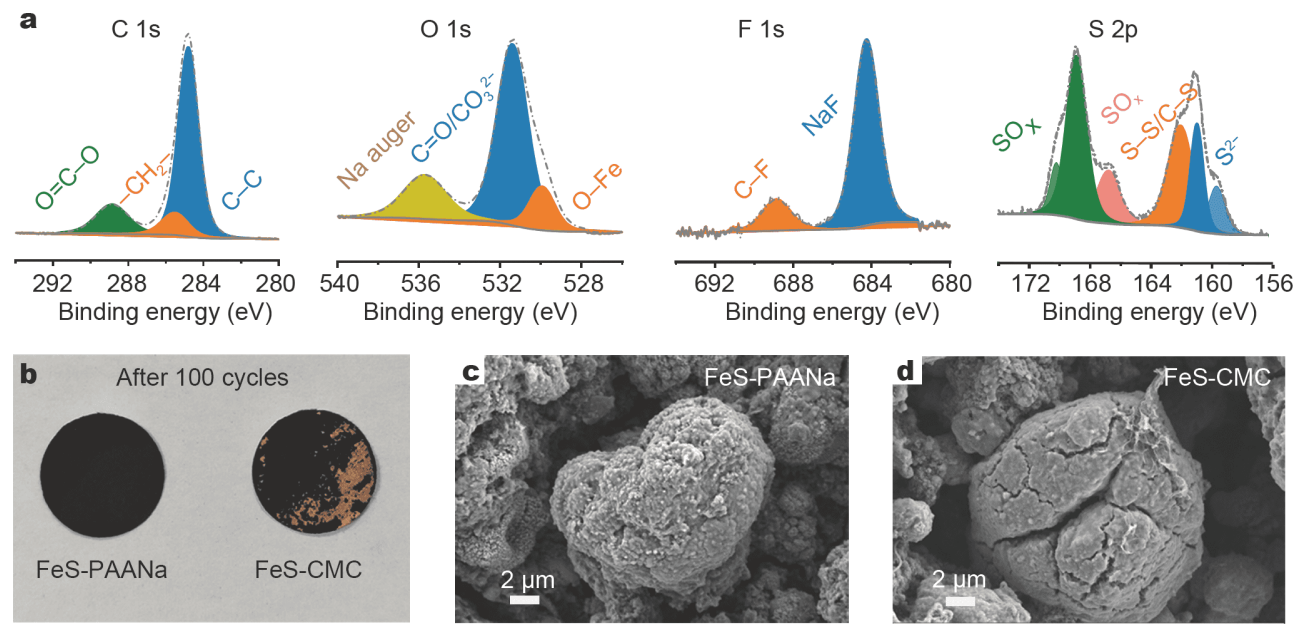

Figure 5 Structure of the FeS-PAANa electrode after cycling. (a) High-resolution XPS patterns for the FeS-PAANa electrode after 50 cycles at discharge state: C 1s, O 1s, F 1s and S 2p. (b) Digital image of the FeS-PAANa and FeS-CMC electrodes after 100 cycles. SEM images of (c) FeSPAANa electrode and (d) FeS-CMC electrode after 100 cycles.

PAANa electrode exhibited low $R_{\mathrm{SEI}}$ of $1.69 \Omega$, higher ion transport property, and excellent rate performance with the capacity of $432.43 \mathrm{~mA} \mathrm{~h} \mathrm{~g}^{-1}$ at a current density of $6 \mathrm{C}$. This work unveils the novel function of PAANa binder and provides a new way to enhance the cyclic stability and rate performance of electrodes.

Received 19 March 2020; accepted 7 May 2020;

published online 13 August 2020

1 Dunn B, Kamath H, Tarascon JM. Electrical energy storage for the grid: a battery of choices. Science, 2011, 334: 928-935

$2 \mathrm{Hu}$ J, Wang Z, Fu Y, et al. In situ assembly of $\mathrm{MnO}_{2}$ nanosheets on sulfur-embedded multichannel carbon nanofiber composites as cathodes for lithium-sulfur batteries. Sci China Mater, 2020, 63: 728-738

3 Wang W, Luo Q, Li B, et al. Recent progress in redox flow battery research and development. Adv Funct Mater, 2013, 23: 970-986

4 Wang Y, Gawryszewska-Wilczynsk P, Zhang X, et al. Photovoltaic efficiency enhancement of polycrystalline silicon solar cells by a highly stable luminescent film. Sci China Mater, 2020, 63: 544-551

5 Lee B, Paek E, Mitlin D, et al. Sodium metal anodes: emerging solutions to dendrite growth. Chem Rev, 2019, 119: 5416-5460

6 Sun $\mathrm{H}, \mathrm{Zhu} \mathrm{G}, \mathrm{Xu} \mathrm{X}$, et al. A safe and non-flammable sodium metal battery based on an ionic liquid electrolyte. Nat Commun, 2019, 10: 3302

7 Chen $\mathrm{H}, \mathrm{Mu} \mathrm{Z}$, Li Y, et al. $\mathrm{SnSe}_{2}$ nanocrystals coupled with hierarchical porous carbon microspheres for long-life sodium ion battery anode. Sci China Mater, 2020, 63: 483-491

8 Sun J, Lee HW, Pasta M, et al. A phosphorene-graphene hybrid material as a high-capacity anode for sodium-ion batteries. Nat Nanotech, 2015, 10: 980-985

9 Palomares V, Serras P, Villaluenga I, et al. Na-ion batteries, recent advances and present challenges to become low cost energy storage systems. Energy Environ Sci, 2012, 5: 5884-5901

10 Ye C, Jiao Y, Chao D, et al. Electron-state confinement of poly- sulfides for highly stable sodium-sulfur batteries. Adv Mater, 2020, 32: 1907557

$11 \mathrm{Xu} \mathrm{X,} \mathrm{Zhou} \mathrm{D,} \mathrm{Qin} \mathrm{X,} \mathrm{et} \mathrm{al.} \mathrm{A} \mathrm{room-temperature} \mathrm{sodium-sulfur}$ battery with high capacity and stable cycling performance. Nat Commun, 2018, 9: 3870

12 Zhang BW, Sheng T, Liu YD, et al. Atomic cobalt as an efficient electrocatalyst in sulfur cathodes for superior room-temperature sodium-sulfur batteries. Nat Commun, 2018, 9: 4082

13 Hueso KB, Palomares V, Armand M, et al. Challenges and perspectives on high and intermediate-temperature sodium batteries. Nano Res, 2017, 10: 4082-4114

14 Zhang J, Song K, Mi L, et al. Bimetal synergistic effect induced high reversibility of conversion-type $\mathrm{Ni@NiCo} \mathrm{S}_{4}$ as a free-standing anode for sodium ion batteries. J Phys Chem Lett, 2020, 11: 14351442

15 Hou B, Wang Y, Ning QL, et al. Self-supporting, flexible, additivefree, and scalable hard carbon paper self-interwoven by $1 \mathrm{D} \mathrm{mi}-$ crobelts: Superb room/low-temperature sodium storage and working mechanism. Adv Mater, 2019, 31: 1903125

16 Jiang X, Liu X, Zeng Z, et al. A bifunctional fluorophosphate electrolyte for safer sodium-ion batteries. iScience, 2018, 10: 114122

17 Li X, Zhi L. Graphene hybridization for energy storage applications. Chem Soc Rev, 2018, 47: 3189-3216

18 Chao D, Ouyang B, Liang P, et al. C-plasma of hierarchical graphene survives $\mathrm{SnS}$ bundles for ultrastable and high volumetric Na-ion storage. Adv Mater, 2018, 30: 1804833

19 Li Y, Lu Y, Meng Q, et al. Regulating pore structure of hierarchical porous waste cork-derived hard carbon anode for enhanced $\mathrm{Na}$ storage performance. Adv Energy Mater, 2019, 9: 1902852

20 Liu J, Zhang Y, Zhang L, et al. Graphitic carbon nitride $\left(\mathrm{g}-\mathrm{C}_{3} \mathrm{~N}_{4}\right)$ derived N-rich graphene with tuneable interlayer distance as a high-rate anode for sodium-ion batteries. Adv Mater, 2019, 31: 1901261

21 Lu P, Sun Y, Xiang H, et al. 3D amorphous carbon with controlled porous and disordered structures as a high-rate anode material for sodium-ion batteries. Adv Energy Mater, 2018, 8: 1702434 
22 Wang T, Yang K, Shi J, et al. Simple synthesis of sandwich-like $\mathrm{SnSe}_{2} / \mathrm{rGO}$ as high initial coulombic efficiency and high stability anode for sodium-ion batteries. J Energy Chem, 2020, 46: 71-77

23 Liu Z, Zhang Y, Zhao H, et al. Constructing monodispersed $\mathrm{MoSe}_{2}$ anchored on graphene: a superior nanomaterial for sodium storage. Sci China Mater, 2017, 60: 167-177

24 Song K, Liu C, Mi L, et al. Recent progress on the alloy-based anode for sodium-ion batteries and potassium-ion batteries. Small, 2019, 1903194

25 Xiong P, Bai P, Li A, et al. Bismuth nanoparticle@carbon composite anodes for ultralong cycle life and high-rate sodium-ion batteries. Adv Mater, 2019, 31: 1904771

26 Lu Y, Chen J. Prospects of organic electrode materials for practical lithium batteries. Nat Rev Chem, 2020, 4: 127-142

27 Wang Y, Wang Y, Wang YX, et al. Developments and perspectives on emerging high-energy-density sodium-metal batteries. Chem, 2019, 5: 2547-2570

28 Fang Y, Luan D, Chen Y, et al. Rationally designed three-layered $\mathrm{Cu}_{2} \mathrm{~S} @$ carbon@ $\mathrm{MoS}_{2}$ hierarchical nanoboxes for efficient sodium storage. Angew Chem Int Ed, 2020, 59: 7178-7183

29 Liu Z, Lu T, Song T, et al. Structure-designed synthesis of FeS $@$ @ yolk-shell nanoboxes as a high-performance anode for sodium-ion batteries. Energy Environ Sci, 2017, 10: 1576-1580

30 Wang W, Li W, Wang S, et al. Structural design of anode materials for sodium-ion batteries. J Mater Chem A, 2018, 6: 6183-6205

31 Chen W, Zhang X, Mi L, et al. High-performance flexible freestanding anode with hierarchical 3D carbon-networks $/ \mathrm{Fe}_{7} \mathrm{~S}_{8}$ /graphene for applicable sodium-ion batteries. Adv Mater, 2019, 31: 1806664

32 Fan H, Qin B, Wang Z, et al. Pseudocapacitive sodium storage of $\mathrm{Fe}_{1-x} \mathrm{~S} @ \mathrm{~N}$-doped carbon for low-temperature operation. Sci China Mater, 2020, 63: 505-515

33 Mogensen R, Brandell D, Younesi R. Solubility of the solid electrolyte interphase (SEI) in sodium ion batteries. ACS Energy Lett, 2016, 1: 1173-1178

34 Muñoz-Márquez MÁ, Saurel D, Gómez-Cámer JL, et al. Na-ion batteries for large scale applications: A review on anode materials and solid electrolyte interphase formation. Adv Energy Mater, 2017, 7: 1700463

35 Song J, Xiao B, Lin Y, et al. Interphases in sodium-ion batteries. Adv Energy Mater, 2018, 8: 1703082

36 Zhang X, Wang B, Wang G, et al. A scalable approach to fabricate metal sulfides/graphene/carbon nanotubes composites with superior electrochemical performances for lithium and sodium ion batteries. Electrochim Acta, 2017, 258: 764-772

37 Li L, Peng S, Bucher N, et al. Large-scale synthesis of highly uniform $\mathrm{Fe}_{1-x} \mathrm{~S}$ nanostructures as a high-rate anode for sodium ion batteries. Nano Energy, 2017, 37: 81-89

38 Hou BH, Wang YY, Guo JZ, et al. A scalable strategy to develop advanced anode for sodium-ion batteries: Commercial $\mathrm{Fe}_{3} \mathrm{O}_{4^{-}}$ derived $\mathrm{Fe}_{3} \mathrm{O}_{4} @ \mathrm{FeS}$ with superior full-cell performance. ACS Appl Mater Interfaces, 2018, 10: 3581-3589

39 Xiao Y, Hwang JY, Belharouak I, et al. Na storage capability investigation of a carbon nanotube-encapsulated $\mathrm{Fe}_{1-x} \mathrm{~S}$ composite. ACS Energy Lett, 2017, 2: 364-372

40 Chen H, Ling M, Hencz L, et al. Exploring chemical, mechanical, and electrical functionalities of binders for advanced energy-storage devices. Chem Rev, 2018, 118: 8936-8982

41 Bommier C, Ji X. Electrolytes, SEI formation, and binders: a review of nonelectrode factors for sodium-ion battery anodes. Small, 2018,
14: 1703576

42 Bie Y, Yang J, Liu X, et al. Polydopamine wrapping silicon crosslinked with polyacrylic acid as high-performance anode for lithium-ion batteries. ACS Appl Mater Interfaces, 2016, 8: 28992904

43 Hernandez CR, Etiemble A, Douillard T, et al. A facile and very effective method to enhance the mechanical strength and the cyclability of Si-based electrodes for Li-ion batteries. Adv Energy Mater, 2018, 8: 1701787

44 Li Q, Yang H, Xie L, et al. Guar gum as a novel binder for sulfur composite cathodes in rechargeable lithium batteries. Chem Commun, 2016, 52: 13479-13482

45 Liu J, Zhang Q, Zhang T, et al. A robust ion-conductive biopolymer as a binder for Si anodes of lithium-ion Batteries. Adv Funct Mater, 2015, 25: 3599-3605

46 Munaoka T, Yan X, Lopez J, et al. Ionically conductive self-healing binder for low cost $\mathrm{Si}$ microparticles anodes in Li-ion batteries. Adv Energy Mater, 2018, 8: 1703138

47 Wang $\mathrm{C}, \mathrm{Wu} \mathrm{H}, \mathrm{Chen} \mathrm{Z}$, et al. Self-healing chemistry enables the stable operation of silicon microparticle anodes for high-energy lithium-ion batteries. Nat Chem, 2013, 5: 1042-1048

48 Xu Z, Yang J, Zhang T, et al. Silicon microparticle anodes with selfhealing multiple network binder. Joule, 2018, 2: 950-961

49 Tang Y, Deng J, Li W, et al. Water-soluble sericin protein enabling stable solid-electrolyte interphase for fast charging high voltage battery electrode. Adv Mater, 2017, 29: 1701828

50 Ma Y, Chen K, Ma J, et al. A biomass based free radical scavenger binder endowing a compatible cathode interface for $5 \mathrm{~V}$ lithiumion batteries. Energy Environ Sci, 2019, 12: 273-280

51 Hu Z, Zhu Z, Cheng F, et al. Pyrite $\mathrm{FeS}_{2}$ for high-rate and long-life rechargeable sodium batteries. Energy Environ Sci, 2015, 8: 13091316

52 Zhu Y, Wang C. Galvanostatic intermittent titration technique for phase-transformation electrodes. J Phys Chem C, 2010, 114: 28302841

53 Eshetu GG, Diemant T, Hekmatfar M, et al. Impact of the electrolyte salt anion on the solid electrolyte interphase formation in sodium ion batteries. Nano Energy, 2019, 55: 327-340

$54 \mathrm{Wu} \mathrm{CY}$, Duh JG. Ionic network for aqueous-polymer binders to enhance the electrochemical performance of Li-ion batteries. Electrochim Acta, 2019, 294: 22-27

55 Baigorri R, García-Mina JM, González-Gaitano G. Supramolecular association induced by $\mathrm{Fe}(\mathrm{III})$ in low molecular weight sodium polyacrylate. Colloids Surfs A-Physicochem Eng Aspects, 2007, 292: 212-216

56 Zhang Z, Gao Z, Wang Y, et al. Eco-friendly, self-healing hydrogels for adhesive and elastic strain sensors, circuit repairing, and flexible electronic devices. Macromolecules, 2019, 52: 2531-2541

57 Wang YX, Yang J, Chou SL, et al. Uniform yolk-shell iron sulfidecarbon nanospheres for superior sodium-iron sulfide batteries. Nat Commun, 2015, 6: 8689

58 Cho JS, Park JS, Kang YC. Porous FeS nanofibers with numerous nanovoids obtained by Kirkendall diffusion effect for use as anode materials for sodium-ion batteries. Nano Res, 2017, 10: 897-907

59 Wang Q, Zhang W, Guo C, et al. In situ construction of 3D interconnected $\mathrm{FeS} @ \mathrm{Fe}_{3} \mathrm{C} @$ graphitic carbon networks for high-performance sodium-ion batteries. Adv Funct Mater, 2017, 27: 1703390

60 Xiao Y, Hwang JY, Sun YK. Micro-intertexture carbon-free iron sulfides as advanced high tap density anodes for rechargeable 
batteries. ACS Appl Mater Interfaces, 2017, 9: 39416-39424

61 Yang D, Chen W, Zhang X, et al. Facile and scalable synthesis of low-cost FeS@C as long-cycle anodes for sodium-ion batteries. J Mater Chem A, 2019, 7: 19709-19718

62 Li K, Zhang J, Lin D, et al. Evolution of the electrochemical interface in sodium ion batteries with ether electrolytes. Nat Commun, 2019, 10: 725

63 Zhang J, Wang DW, Lv W, et al. Achieving superb sodium storage performance on carbon anodes through an ether-derived solid electrolyte interphase. Energy Environ Sci, 2017, 10: 370-376

64 Seh ZW, Sun J, Sun Y, et al. A highly reversible room-temperature sodium metal anode. ACS Cent Sci, 2015, 1: 449-455

$65 \mathrm{Lu} \mathrm{Q}, \mathrm{He} \mathrm{YB}, \mathrm{Yu} \mathrm{Q}$, et al. Dendrite-free, high-rate, long-life lithium metal batteries with a 3D cross-linked network polymer electrolyte. Adv Mater, 2017, 29: 1604460

66 Shen Z, Cao L, Rahn CD, et al. Least squares galvanostatic intermittent titration technique (LS-GITT) for accurate solid phase diffusivity measurement. J Electrochem Soc, 2013, 160: A1842A1846

67 Ling L, Bai Y, Wang Z, et al. Remarkable effect of sodium alginate aqueous binder on anatase $\mathrm{TiO}_{2}$ as high-performance anode in sodium ion batteries. ACS Appl Mater Interfaces, 2018, 10: 55605568

Acknowledgements This work was supported by the National Natural Science Foundation of China (U1804129, 21771164, 21671205 and U1804126), Zhongyuan Youth Talent Support Program of Henan Province and Zhengzhou University Youth Innovation Program.

Author contributions Chen L prepared the samples, collected the data and wrote the original draft. Zhang J analyzed the XPS data. Shi J provided support for the electrochemical analysis. Song $\mathrm{K}$ provided support for the writing of the paper. Mi L conducted the XPS and SEM studies. Chen W, Liu C and Shen C supervised the project and co-wrote the paper. All authors contributed to the writing and editing of the manuscript.

Conflict of interest The authors declare that they have no conflict of interest.

Supplementary information Experimental details and supporting data are available in the online version of the paper.

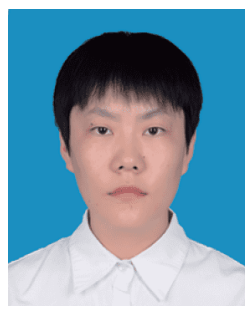

Linjie Chen is currently a master student at the National Engineering Research Center for Advanced Polymer Processing Technology of Zhengzhou University. Her present research interests are the working mechanism of polymer binder and its influence on electrochemical performance in sodium-ion batteries.

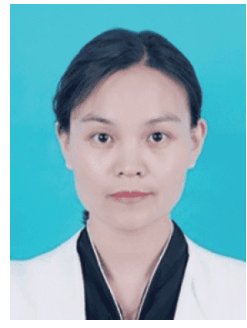

Weihua Chen is a professor at Zhengzhou university, China. She received her $\mathrm{PhD}$ degree in physical chemistry from Wuhan university, China (2009) and her BSc degree in chemistry from Zhengzhou University, China (2004). Her research interests focus on electrochemistry, green energy storage system and their key materials, electrode/solution interface.

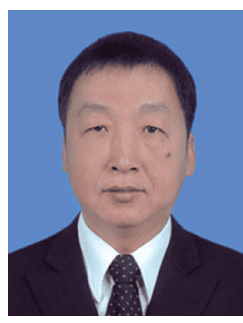

Chuntai Liu is a professor in the National Engineering Research Center for Advanced Polymer Processing Technology (NERC) of Zhengzhou University. He obtained his BSc and MSc degrees, respectively from Peking University (1987) and Xi'an Jiaotong University (1993), and his $\mathrm{PhD}$ degree from Zhengzhou University (2003). He worked as a visiting scholar at the Ohio State University (2006-2007). He now serves as the deputy director of NERC of Zhengzhou University. His research focuses on multifunctional polymer composites including processing-microstructure-properties.

\section{PAANa粘结剂诱导形成柔韧固态电解质膜提升微 米级 FeS电极的储钠性能}

陈林洁 ${ }^{1}$, 宋轫铭 ${ }^{2}$, 石娟 ${ }^{2,3}$, 张继雨 ${ }^{2}$, 米立伟 ${ }^{3}$, 陈卫华 ${ }^{1,2}$, 刘春太 ${ }^{1 *}$, 申长雨 ${ }^{1}$

摘要 高容量金属硫化物面临着首周库伦效率低、穿梭效应和体 积膨胀等导致的严重容量衰退问题, 碳包覆和固定常被用来解决 上述问题. 然而, 这些方法通常比较复杂、耗时, 不利于大规模应 用. 本文提出一种采用粘结剂优化解决微米级 FeS 电极材料上述问 题的简便策略, 以极性聚合物粘结剂聚丙烯酸钠(PAANa)为例, 研 究了其作用机制: PAANa粘结剂的引入可与FeS材料颗粒形成交联 的网状结构, 既可以缓冲电极材料在充放电时体积的改变所产生 的机械应力, 还诱导并参与在FeS颗粒表面形成较薄的SEI膜, 提高 了电极界面离子迁移速度和电极的首周库伦效率, 使得 $\mathrm{FeS}$ 负极的 循环稳定性和倍率性能得到明显优化. 本工作不仅使人们对电极 粘结剂在电极中的作用有了新的认识, 而且为优化电池材料性能 提供了新途径. 